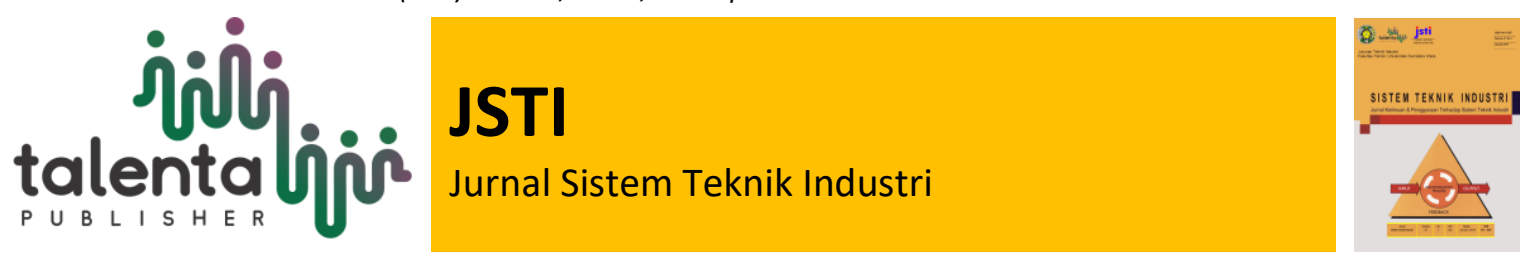

\title{
ANALISA PERSEDIAAN LIMBAH KERING PABRIK KELAPA SAWIT SEBAGAI BAHAN BAKAR PEMBANGKIT LISTRIK PTPN IV KEBUN ADOLINA
}

\section{Luthfi Parinduri1, Mahrani Arfah1, Jepri Sahputra1}

${ }^{1}$ Fakultas Teknik Universitas Islam Sumatera Utara

\begin{abstract}
Abstrak. PKS PTPN IV KEBUN ADOLINA, Merupakan Perusahaan yang bargerak dalam bidang pengolahan kelapa sawit, dan dalam aktivitas produksinya mempertimbangkan faktor-faktor produksi. Boiler merupakan sarana pendukung yang sangat pentinng dan mempunyai pengaruh sangat besar terhadap aktivitas pengolahan di pabrik kelapa sawit. Tujuan penelitian ini adalah menganalisa ketersediaan cangkang dan serabut kelapa sawit dalam sistem operasi boiler yang nantinya dapat diketahui apakah persediaan TBS olah mencukupi kebutuhan bahan bakar boiler pada saat pengolahan berlangsung, dan menganalisa kebutuhan rata-rata bahan bakar cangkang dan serabut yang dibutuhkan pada setiap tahunnya. Dalam hal ini, dari kapasitas olah TBS $30.000 \mathrm{~kg} / \mathrm{jam}$ pada bulan Maret 2018 sampai dengan bulan Februari 2019 menghasilkan bahan bakar cangkang rata-rata sebanyak $814.495 \mathrm{~kg}$ dan serabut sebanyak $1.553 .473 \mathrm{~kg}$. Cangkang yang digunakan sebanyak $730.375 \mathrm{~kg}$ serta serabut $1.462 .336 \mathrm{~kg}$.. Dari pengolahan dan analisa data dapat disimpulkan bahwa bahan bakar cangkang dan srabut yang dihasilkan dari proses produksi sampingan pabrik dapat memenuhi kebutuhan bahan bakar boiler.
\end{abstract}

Kata Kunci: Cangkang, Serabut Kelapa Sawit , Boiler

\begin{abstract}
PKS PTPN IV KEBUN ADOLINA, is a company engaged in the field of palm oil processing, and in its production activities taking into account the factors of production. Boilers are a very important supporting means and have a very big influence on processing activities in palm oil mills. The purpose of this study is to analyze the availability of oil palm shells and fibers in the boiler operating system which can later be known whether the supply of FFB if sufficient supply of boiler fuel during processing takes place, and analyze the average needs of shell and fiber fuels needed each year. In this case, the FFB capacity of $30,000 \mathrm{~kg} / \mathrm{hour}$ in March 2018 to February 2019 produces an average of 814,495 $\mathrm{kg}$ of shell fuel and 1,553,473 $\mathrm{kg}$ of fibers. The shells used are 730,375 $\mathrm{kg}$ and 1,462,336 $\mathrm{kg}$ of fibers. From the processing and analysis of data it can be concluded that the shell and srabut fuel produced by the factory side production process can meet the needs of boiler fuel.
\end{abstract}

Keyword: Shell, Palm Oil, Boiler

Received 11 July 2019 | Revised 25 July 2019 | Accepted 25 July 2019

*Corresponding author at: Jl. Sisingamangaraja Teladan, Kota Medan, Indonesia

E-mail address: luthfip@yahoo.co.id, mahrani.arfah@ft.uisu.ac.id, jepri.sa04@gmail.com 


\section{Introduction}

Kelapa sawit merupakan salah satu komoditi hasil perkebunan yang menjadi andalan Indonesia saat ini untuk mendatangkan devisa negara. Salah satu provinsi yang menyumbang hasil perkebunan kelapa sawit terbesar yaitu Sumatera Utara dengan luas lahan mencapai 1.290.977 ha dengan jumlah produksi 3.996.465 ton (Statistik Kelapa Sawit Indonesia, 2017-2018). Sejalan dengan semakin meningkatnya produksi kelapa sawit dari tahun ketahun, maka akan terjadi pula peningkatan volume limbahnya, baik berupa limbah padat maupun limbah cair. Limbah padat kelapa sawit dapat berupa tandan kosong, cangkang, dan serabut sedangkan limbah cairnya berupa bahan-bahan organic dengan kadar yang tinggi.

Kebutuhan listrik pada industri merupakan hal yang sangat penting, oleh sebab itu diciptakanlah suatu alat yang disebut boiler untuk menghasilkan daya listrik dan uap air. Boiler merupakan pilihan yang menguntungkan untuk memenuhi tujuan ini. Untuk memenuhi kebutuhan energi yang semakin meningkat sementara cadangan bahan bakar yang semakin hari semakin menipis serta tuntutan keamanan yang tinggi bagi manusia dan lingkungan, maka dilakukan suatu perencanaan boiler dengan efisiensi yang tinggi. Boiler di bidang industri banyak dijumpai pemanfaatannya. Boiler menghasilkan Steam yang panasnya digunakan sebagai media pemanas, pengering, pengawet proses dan pembangkit energi.

Cangkang dan serabut kelapa sawit merupakan salah satu limbah yang dimiliki oleh pabrik kelapa sawit PT. PERKEBUNAN NUSANTARA IV KEBUN ADOLINA yang kemudian dimanfaatkan sebagai bahan bakar pada stasiun boiler. Berdasarkan hal tersebut, maka penulis mencoba merumuskan penggunaan bahan bakar kernel kelapa sawit untuk mengoperasikan boiler dengan memperhatikan permasalahan berikut:

a. Berapa banyak jumlah persediaan cangkang dan serabut yang dibutuhkan untuk mengoperasikan Boiler dengan kapasitas TBS yang akan diolah pada tahun 2018 maret februari 2019.

b. Berapa jumlah persediaan TBS untuk menghasilkan kernel sebagai bahan bakar Boiler selama periode 2018 maret - 2019 februari

c. Berapa total persediaan kernel PT. PERKEBUNAN NUSANTARA IV KEBUN ADOLINA selama periode 2018 maret - februari 2019.

Adapun tujuan penelitan ini adalah :

a. Mengetahui konsumsi cangkang dan serabut yang dibutuhkan untuk memenuhi kebutuhan Boiler

b. Mengetahui penghematan yang bisa dilakukan dengan mengurangi pemakaian bahan bakar solar sebagai pengoperasian boiler dengan menggunakan bahan bakar cangkang dan serabut. 


\section{Studi Literatur}

\subsection{Pengertian Boiler}

Boiler/ketel uap merupakan bejana tertutup dimana panas pembakaran dialirkan ke air sampai terbentuk air panas atau steam berupa energi kerja. Air adalah media yang berguna dan murah untuk mengalirkan panas ke suatu proses. Air panas atau steam pada tekanan dan suhu tertentu mempunyai nilai energi yang kemudian digunakan untuk mengalirkan panas dalam bentuk energi kalor ke suatu proses. Jika air didihkan sampai menjadi steam, maka volumenya akan meningkat sekitar 1600 kali, menghasilkan tenaga yang menyerupai bubuk mesiu yang mudah meledak, sehingga sistem boiler merupakan peralatan yang harus dikelola dan dijaga dengan sangat baik.

Boiler sering juga di sebut orang ketel uap. Di dalam pabrik kelapa sawit boiler bisa dikatakan peringkat utama sebagai sumber tenaga suatu pabrik. Uap yang di hasilkan oleh boiler di gunakan sebagai :

a. Penggerak pesawat uap (sistem engine) yang di sebut turbin.

b. Pemanasan .

c. Rebusan (Sterilizer).

d. Pengadukan (Digester).

e. Tangki-tangkiminyak yang ada di pabrik.

f. Kernel storage.

g. Serta tenaga listrik dalam pabrik

Energi kalor yang dibangkitkan dalam sistem boiler memiliki nilai tekanan, temperatur, dan laju aliran yang menentukan pemanfaatan steam yang akan digunakan. Berdasarkan ketiga hal tersebut sistem boiler mengenal keadaan tekanan-temperatur rendah (low pressure/LP), dan tekanan-temperatur tinggi (high pressure/HP), dengan perbedaan itu pemanfaatan steam yang keluar dari sistem boiler dimanfaatkan dalam suatu proses untuk memanasakan cairan dan menjalankan suatu mesin (commercial and industrial boilers), atau membangkitkan energi listrik dengan merubah energi kalor menjadi energi mekanik kemudian memutar generator sehingga menghasilkan energi listrik (powerboilers).

Namun, ada juga yang menggabungkan kedua sistem boiler tersebut, yang memanfaatkan tekanan-temperatur tinggi untuk membangkitkan energi listrik, kemudian sisa steam dari turbin dengan keadaan tekanan-temperatur rendah dapat dimanfaatkan ke dalam proses industri.

Untuk mengetahui lebih lanjut mengenai boiler terlebih dahulu harus memenuhi beberapa hal antara lain sebagai berikut : 
a. Pressure atau tekanan adalah tekanan kerja yang dihasilkan oleh steam boiler

b. Temperatur atau suhu adalah panas yang dihasilkan steam boiler.

c. Kapasitas adalah kemampuan boiler untuk menghasilkan uap dalam setiap ton/jam. Untuk mencari kapasitas boiler rumus yang digunakan adalah :

Keterangan

$$
\mathrm{Q}=\frac{n \times G B B X N . K}{\Delta \text { Entalphy }}
$$

Q $\quad=$ Kapasitas kg/hari

$\eta \quad=$ Efisiensi Boiler $73 \%$

Gbb = Berat Bahan Bakar kg/hari

N.k = Nilai Kalor $\mathrm{kcal} / \mathrm{kg}$

$\Delta$ Entalphy $=$ Perbedaan Entalphy Uap Dan Entalphy Air Masuk kcal/kg

a. Efisiensi adalah suatu ukuran berapa banyak steam yang dihasilkan setiap ton bahan bakar yang terbakar didalam ruang dapur. Rumus yang digunakan untuk mendapatkan efisiensi adalah

$$
\eta=\frac{Q \Delta \text { Entalphy }}{G b b \times N \cdot K}
$$

Keterangan

Q $\quad=$ Kapasitas kg/hari

$\eta \quad=$ Efisiensi Boiler $73 \%$

$\mathrm{Gbb}=$ Berat Bahan Bakar kg/hari

N.k = Nilai Kalor kcal/kg

\subsection{Pengaruh Bahan Bakar Terhadap Jumlah Uap Dan Listrik Yang Dihasilkan}

Dalam proses pengolahan kelapa sawit uap diperlukan untuk pembangkit tenaga listrik dan sumber panas pada proses pengolahan kelapa sawit.Sehingga, jika kapasitas produksi uap menurun maka akan terjadi gangguan terhadap turbin yang menyebabkan penurunan produksi tenaga listrik dan penurunan efisiensi pengolahan,hal ini bisa dilihat dari kapasitas produksi TBS.

Penurunan kapasitas produksi uap dapat disebabkan oleh kurangnya bahan bakar boiler. Boiler yang dioperasikan di PT. PERKEBUNAN NUSANTARA IV KEBUN ADOLINA melakukan 
pengisian bahan bakar dengan kapasitas dan tekanan kerja yang sesuai dengan kebutuhan turbin sehingga meningkatkan stabilitas turbin. Karena kontinuitas pengisian bahan bakar untuk boiler didasarkan pada tekanan boiler, apabila tekanan uap boiler rendah maka akan dilakukan pengisian bahan bakar dengan cepat dan sesuai agar tidak menyebabkan tekanan tidak turun secara tibatiba.

Cara ini dapat mengatasi penurunan tekanan uap, akan tetapi sering terjadi perubahan keseimbanganbahan bakar dengan udara yakni jumlah bahan bakar yang dimasukkan terlalu banyak dan volume udara yang menurun akibatnya ruang bakar menjadi sempit dan mengakibatkan pembakaran menjadi tidak sempurna.

\subsection{Jenis - Jenis Bahan Bakar Boiler}

Bahan bakar yang digunakan didalam Boiler pada umumnya diklasifikasikan sebagai berikut:

a. Bahan bakar padat

Jenis Boiler ini menggunakan bahan padat seperti batu bara, kayu, cangkang, dengan karateristik seperti harga bahan bakar relatif lebih murah dan lebih efisiensi bila dibandingkan dengan boiler listrik.

Prinsip Kerja : Pemanasan berssumber dari pembakaran bahan bakar padat atau bisa juga campuran dari beberapa bahan bakar padat ( batu bara, kayu, kernel) yang dibantu dengan oksigen.

Kelebihan : Bahan bakar ,mudah untuk didapatkan dan lebih murah serta sebagai pemanfatan limbah pada yaitu kernel.

Kekurangan : Sisa pembakaran sulit untuk dibersihkan.

b. Bahan bakar cair

Jenis ini memiliki bahan bakar dari Fraksi minyak bumi dengan karakteristik yaitu memiliki bahan baku pembakaran yang lebih mahal, tetapi memiliki nilai efisiensi yang lebih baik jika dibandingkan dengan yang lainya.

Prinsip Kerja : Pemanasan yang bersumber dari hasil pembakaran antara campuran bahan bakar cair (kerosen, solar, residu) dengan oksigen dan sumber panas.

Kelebihan : Memiliki sisa pembakaran yan sedikit sehingga mudah dibersihkan dan bahan baku yang mudah didapatkan

Kekurangan : Harga bahan baku yang relatif mahal. 
c. Bahan bakar gas

Memiliki jenis bahan bakar gas dengan karateristik bahan baku yang lebih murah dan nilai efisiensi lebih baik jika dibandingkan dengan jenis tipe bahan bakar lain.

Prinsip Kerja : Pembakaran yang terjadi akibat campuran dari bahan bakar gas (LNG) dengan oksigen serta sumber panas.

Kelebihan : Memiliki bahan bakar yang paling murah dan nilai efisiensi yang lebih baik.

Kekurangan : Kontruksi yang mahal dan sumber bahan bakar yang sulit di dapat.

Pada umumnya Boiler pada pabrik kelapa sawit menggunakan bahan bakar padat buatan yang mudah diperoleh, dan ekonomis yaitu sebagai serabut dan cangkang kelapa sawit, bila dibandingkan dengan bahan bakar lainnya

\subsection{Kandungan Panas Pembakaran Cangkang Dan Serabut}

Bahan bakar yang digunakan PT. PERKEBUNAN NUSANTARA IV KEBUN ADOLINA untuk mesin boiler adalah cangkang dan serabut kelapa sawit yang dihasilkan dari limbah padat pengolahan TBS oleh pabrik itu sendiri.Dengan manajemen yang benar maka operasional pabrik kelapa sawit tidak perlu dibantu dengan genset, kecuali pada awal dan akhir masing - masing selama satu jam.

Nilai kalor untuk masing - masing komponen bahan bakar telah ditentukan oleh "Blommedal" yaitu sebagai berikut :

Bahan Bakar Cangkang :

a. Zat Padat $\quad: 4700 \mathrm{kcal} / \mathrm{kg}$ Kernel

b. Minyak $\quad: 8800 \mathrm{kcal} / \mathrm{kg}$

c. Panas yang diperlukan untuk penguapan air adalah $600 \mathrm{kcal} / \mathrm{kg}$ air

Bahan Bakar Serabut

a. Zat Padat : $3850 \mathrm{kcal} / \mathrm{kg}$ Serabut

b. Minyak $\quad: 8800 \mathrm{kcal} / \mathrm{kg}$

c. Panas yang diperlukan untuk penguapan air adalah $600 \mathrm{kcal} / \mathrm{kg}$ air

Bila hasil analisa kempa diperoleh komposisi kandungan bahan seperti ditunjukkan pada tabel 2.1 
Table 1 Komposisi Kandungan Bahan Bakar

\begin{tabular}{lcc}
\hline \multicolumn{1}{c}{ Komposisi } & Cangkang $(\%)$ & Serabut $(\%)$ \\
\hline Kadar Zat Padat & 82,85 & 56.14 \\
Kadar Minyak & 1,06 & 4.38 \\
Kadar Air & 16,09 & 39.48 \\
Sumber : PKS Kebun Adolina &
\end{tabular}

\subsection{Menghitung Nilai Kalor Cangkang Dan Serabut}

Nilai kalor merupakan energi kalor yang dilepaskan bahan bakar pada waktu terjadinya oksidasi unsur-unsur kimia yang ada pada bahan bakar tersebut. Nilai kalor pada bahan bakar dapat dibagi menjadi dua menurut yaitu :

a. Nilai Kalor Bahan Bakar Tertinggi (HHV)

Nilai kalor bahan bakar tertinggi atau high heating value(HHV), uap air yang terbentuk dari hasil pembakaran dicairkan terlebih dahulu sehingga panas pengembunannya akan turut dihitung sebagai panas pembakaran yang terbentuk. (Djokosetyardjo, 1999).

b. Nilai Kalor Bahan Bakar Terendah (LHV)

Nilai kalor bahan bakar terendah atau lowest heating value (LHV), uap air yang terbentuk dari hasil pembakaran tidak perlu dicairkan terlebih dahulu, sehingga panas pengembunnanya tidak ikut serta dihitung dengan panas pembakaran bahan bakar tersebut (Djoko setyardjo, 1999).

Cangkang sawit PT. PERKEBUNAN NUSANTARA IV KEBUN ADOLINA sebagai alternatif bahan bakar mesin boiler, cangkang pada buah sawit merupakan bagian terkeras pada komponen yang terdapat pada TBS. Sehinnga memiliki banyak kegunaan serta manfaat bagi industri, usaha maupun rumah tangga. Beberapa diantaranya adalah produk bernilai ekonomis tinggi seperti karbon aktif, asap cair, fenol, beriket arang, dan tepung tempurung. Seacara garis besar, cangkang sawit yang sering dimanfaatkan memiliki kegunaan sebagai berikut :

a. Sebagai bahan baku arang atau charcoal dan juga briket

b. Sebagai bahan bakar mesin boiler

c. Cangkang sawit juga sering dipakai sebagai pengeras halaman khususnya diarea sekitaran pabrik

Kalor adalah suatu bentuk energi yang diterima oleh suatu benda yang menyebabkan benda tersebut berubah suhu atau wujud bentuknya. Kalor berbeda dengan suhu, karena suhu adalah ukuran dalam satuan derajat panas. Untuk menghitung kadar kalori yang dihasilkan dari sebuah zat menggunakan rumus sebagai berikut : 


$$
\mathrm{Q}=\mathrm{m} \cdot \mathrm{c}(\mathrm{t} 2-\mathrm{t} 1)
$$

Keterangan :

$$
\begin{array}{ll}
\mathrm{Q} & =\text { Kalor yang dibutuhkan }(\mathrm{j}) \\
\mathrm{m} & =\text { Massa benda }(\mathrm{kg}) \\
\mathrm{c} & =\text { Kalor jenis }(\mathrm{j} / \mathrm{kg}) \\
(\mathrm{t} 2-\mathrm{t} 1) & =\text { Perubahan suhu }(\mathrm{c}
\end{array}
$$

\begin{tabular}{|c|c|c|c|c|c|c|}
\hline No & Bahan & $\begin{array}{l}\text { Kadar } \\
\text { (Air) } \%\end{array}$ & $\begin{array}{l}\text { Kadar } \\
\text { Abu \% }\end{array}$ & $\begin{array}{c}\text { Kadar } \\
\text { Volatil } \\
\%\end{array}$ & $\begin{array}{c}\text { Kadar } \\
\text { Karbon } \\
\text { Terlihat } \%\end{array}$ & $\begin{array}{l}\text { Nilai } \\
\text { Kalor(kal/gr) }\end{array}$ \\
\hline 1 & Batu Bara & 4,77 & 8,76 & 41,91 & 44,54 & 5619,16 \\
\hline 2 & Arang Batu Bara & 1,39 & 13,32 & 29,25 & 56,12 & 6543,50 \\
\hline 3 & Serabut Kelapa Sawit & 25,32 & 4,83 & 52,01 & 17,82 & 3809,30 \\
\hline 4 & $\begin{array}{l}\text { Arang Serabut Kelapa } \\
\text { Sawit }\end{array}$ & 1,56 & 11,97 & 15,98 & 70,47 & 6231,22 \\
\hline 5 & Cangkang Kelapa Sawit & 21,77 & 3,51 & 53,36 & 21,34 & 5112,56 \\
\hline 6 & $\begin{array}{l}\text { Arang Cangkang } \\
\text { Kelapa Sawit }\end{array}$ & 0,994 & 6,87 & 15,53 & 76,37 & 6877,32 \\
\hline 7 & Solar & - & - & - & - & 10935,3 \\
\hline
\end{tabular}

Table 2 Data Hasil Pengujian Nilai Kalor

Sumber : Prosiding Seminar Nasional Aplikasi Sains \& Teknologi (SNAST) Priode III

Table 3 Besar Biomassa PKS

\begin{tabular}{ccccc}
\hline No & Biomassa & Bentuk & Jumlah (\%) & $\begin{array}{c}\text { Calori } \\
\text { (Kcal) }\end{array}$ \\
\hline 1 & Serabut & Padat & $22-23$ & 4492 \\
2 & Cangkang & Padat & $12-14$ & $2637-4554$ \\
\hline \multicolumn{5}{l}{ Sumber $:$ Journal Of Electrical Technology vol. 1, no 2, juni 2016 }
\end{tabular}

Menurut Dr. Ir Takal Barus, energi terbarukan PKS 30 TBS /Jam bila diolah 300.000 ton TBS /tahun dan randemen cangkang sebanyak 7\% dari 300.000 ton hasilnya 21.000 ton cangkang dengan nilai bahan bakar 3000 k.kal hingga 6000 k. Kal /kg.

Untuk menghitung bahan bakar yang tersedia pada Palm Oil Mill (P.O.M) ton TBS /Jam.

Serabut $=7 \%$ Kapasitas ton

Untuk mengitung Nilai Kalor Kernel (N.K)

Dengan Komposisi :

Kadar Air (Water) $\quad=23,5 \%$ x Cangkang kg

Kadar Zat Padat (NOS) $=75,9 \%$ x Cangkang kg

Kadar Minyak (OIL) $\quad=0,6 \% \quad x$ Cangkang $\mathrm{kg}$ 
Heating Value

Kadar Zat Padat $\quad=4700 \mathrm{Kcal} / \mathrm{kg}$

Kadar Minyak $(\mathrm{OIL}) \quad=8800 \mathrm{Kcal} / \mathrm{kg}$

Untuk mencari N.K. Cangkang dapat digunakan rumus :

$\frac{\text { (NOS Shell x H V Nos Shell)+ ( OIL Shell x H V OIL)- (H E Water x Water) }}{\text { Cangkang (kg) }} \mathrm{Kcal} / \mathrm{kg}$

Untuk Menghitung Nilai Kalor Serabut

Dengan Komposisi :

Kadar Air ( Water) $\quad=39,8 \%$ x Cangkang kg

Kadar Zat Padat $(\mathrm{NOS})=55,6 \%$ x Cangkang kg

Kadar Minyak $(\mathrm{OIL}) \quad=4,65 \%$ x Cangkang $\mathrm{kg}$

Heating Value

Kadar Zat Padat $\quad=3850 \mathrm{Kcal} / \mathrm{kg}$

Kadar Minyak $(\mathrm{OIL}) \quad=8800 \mathrm{Kcal} / \mathrm{kg}$

Untuk mencari N.K. Serabut dapat digunakan rumus :

Keterangan

$\frac{(\text { NOS Fiber x H V Nos ) + ( OIL x H V OIL)- (H E Water x Water) }}{\text { Serabut (kg) }}$ Kcal/kg

NOS : Kadar Zat Padat

HV : Heating Value (Nilai Panas)

HE : Hat Evaporation(Penguapan panas) 


\section{Metodologi Penelitian}

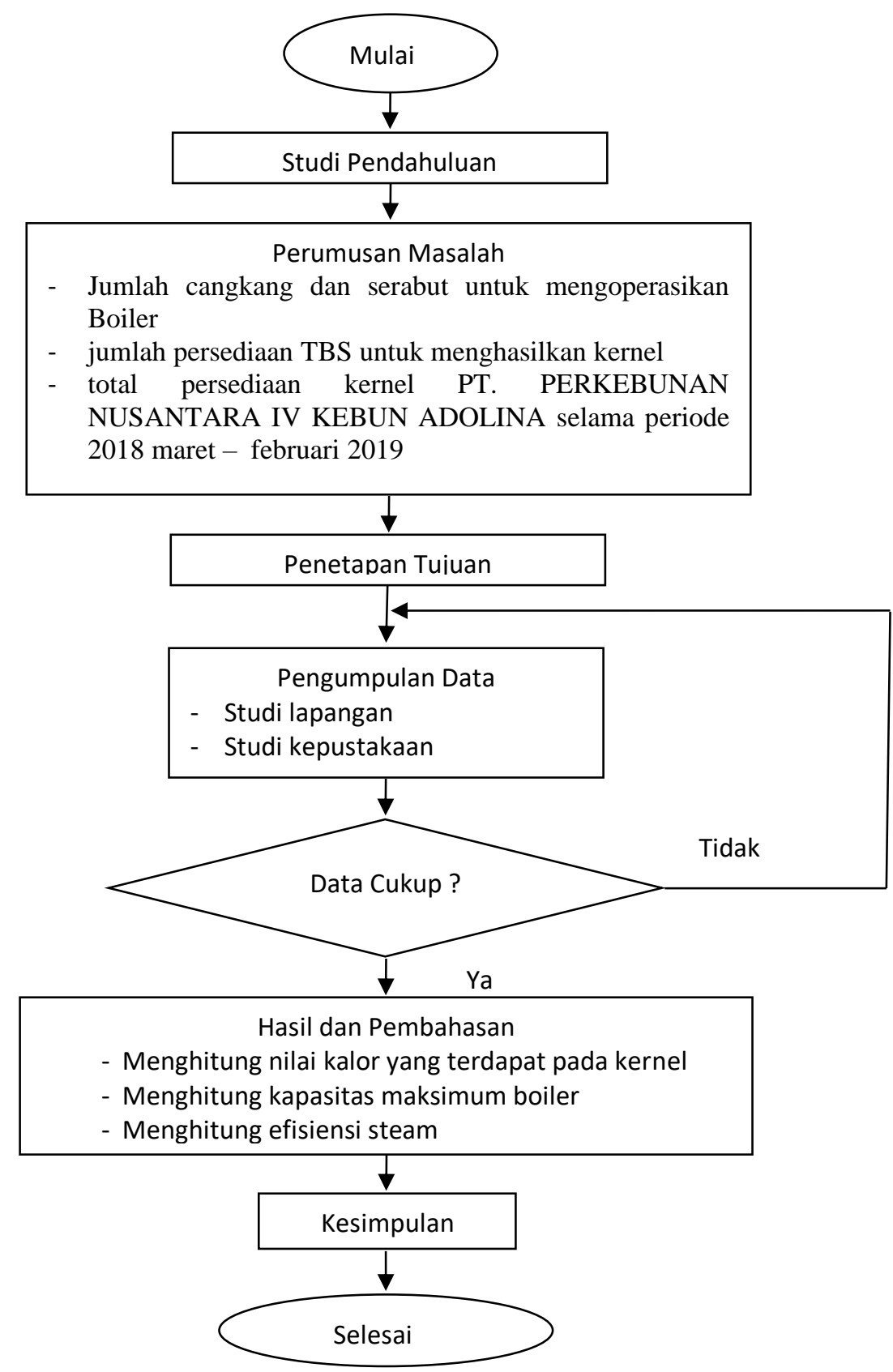

Figure 1 Flowchart Penelitian

\section{Hasil dan Pembahasan}

Untuk dapat melakukan perhitungan persedian kebutuhan bahan bakar boiler ada beberapa syarat yang harus diketahui yaitu :

a. Jenis buah yang diolah di PKS Kebun Adolina

b. Data produksi TBS per bulan

c. Data kandungan panas pada cangkang dan serabut pada TBS

d. Data kalori pada cangkang dan serabut yang terkandung. 
Dari data yang diperoleh di PKS Kebun Adolina jenis buah yang diolah sebagian besar ialah jenis tenera. Berikut adalah data jenis-jenis dan kandungan yang terdapat di dalamnya.

Table 4 Jenis-Jenis Buah Sawit

\begin{tabular}{cccccc}
\hline Varietas & $\begin{array}{c}\text { Cangkang } \\
(\mathrm{mm})\end{array}$ & Pericarp(\%) & $\begin{array}{c}\text { Cangkang } \\
\text { (\%buah) }\end{array}$ & $\begin{array}{c}\text { Mesocarp } \\
(\% \text { buah })\end{array}$ & Inti(\%buah) \\
\hline Dura & $2,5-6$ & $2-6$ & $25-50$ & $20-65$ & $3-20$ \\
Psifera & - & $5-10$ & - & $92-97$ & $3-8$ \\
Tenera & $1-2,5$ & $3-10$ & $3-20$ & $60-90$ & $3-15$ \\
\hline
\end{tabular}

Penggunaan solar sebagai bahan bakar boiler masih tetap dilakukan PTVN IV Kebun Adolina, hal ini dilakukan untuk proses menghidupkan mesin boiler pagi hari hingga beberapa jam sampai boiler dapat berfungsi normal.

Table 5 Perhitungan Rata - Rata Pemakaian Bahan Bakar Solar/Liter

\begin{tabular}{cc}
\hline Tahun & Rata-Rata Operasi Boiler \\
\hline Maret 2016 - Februari 2017 & 541 \\
Maret 2017 - Februari 2018 & 558 \\
Maret 2018 - Februari 2019 & 572 \\
Jumlah & 1.671 \\
Rata-Rata & 557 \\
\hline
\end{tabular}

Dari data pada tabel diatas dapat disimpulkan bahwa kebutuhan bahan bakar boiler dengan menggunakan solar rata - rata dari bulan maret 2016 - februari 2019 berjumlah 557 liter/bulan, jika dikalikan dengan harga solar yang mencapai Rp. 9.800/liter maka PKS Kebun Adolina akan mengeluarkan biaya sebesar Rp. 5.458.600.

Data produksi TBS yang diambil sebagai acuan ialah data produksi dalam kurun waktu satu tahun yang lalu yang dimulai sejak maret 2016 - februari 2019. Berikut adalah data produksi TBS PKS PTVN IV Kebun Adolina. Untuk mengetahui jam operasi boiler dapat dilakukan perhitungan sebagai berikut :

Jam Operasi Boiler $=\frac{\text { TBS Olah } \mathrm{KG}}{\text { Kapasitas Pabrik Kg/Jam }}$

Jam operasi boiler pada bulan januari 2016

Jam Opersai Boiler $=\frac{14.857 .930 \mathrm{Kg}}{30.000 \mathrm{Kg} / \mathrm{Jam}}$

$$
=495 \mathrm{Jam} \text {. }
$$


Table 6 Perhitungan Rata-Rata Operasi Boiler

\begin{tabular}{cc}
\hline Tahun & Rata-Rata Operasi Boiler \\
\hline $2016-2017$ & 16.96 \\
$2017-2018$ & 17.62 \\
$2018-2019$ & 18.23 \\
Jumlah & 53.11 \\
Rata-Rata & 17,70 \\
\hline
\end{tabular}

Table 7 Pemakaian Daya Per Stasiun Di PTPN IV Kebun Adolina

\begin{tabular}{ccc}
\hline Stasiun & Tenaga Terpasang (A) & Tenaga Terpakai(A) \\
\hline Thresher,Loading Ram,Capstand & 102 & 53,6 \\
Press & 135 & 71,20 \\
Deferycarper & 54 & 26,86 \\
Ripple Mill & 74 & 37,81 \\
Kernel & 54 & 26,86 \\
Klarifikasi & 123 & 64,63 \\
Boiler No 1 & 174 & 92,54 \\
Boiler No 2 & 158 & 83,79 \\
Water Pump & 94 & 37,81 \\
Penerangan Pondok & 68 & 34,53 \\
Panel Penerangan Pondok & 55 & 27,41 \\
Jumlah & 1,091 & 557,04 \\
\hline
\end{tabular}

Adapaun data - data mengenai spesifikasi peralatan yang ada dialam pabrik PKS Kebun Adolina terutama Boiler ialah :

\section{Boiler NO 1}

Merk

Type

Tahun Pembuatan

Jenis Ketel Uap

Kapasitas

Suhu Air Umpan

Temperatur Uap

Tekanan Kerja Max $\left(\mathrm{Kg} / \mathrm{cm}^{2}\right)$

Suhu Uap Lanjut

Temperatur Gas Buang

Luas Pemanas
: Pepcock

: Water Tube Boiler

: 1986

: K. Uap Darat Tetap

: $18-20$ ton/jam

$: 90^{\circ} \mathrm{c}$

$: 280^{\circ} \mathrm{c}$

: 24

$: 260^{\circ} \mathrm{c}$

$: 370^{\circ} \mathrm{c}$

: $634 \mathrm{~m}^{2}$ 
Luas Panggang $\quad: 12 / \mathrm{m}^{2}$

\section{Boiler NO 2}

Merk

Type

Tahun Pembuatan

Jenis Ketel Uap

Kapasitas

Suhu Air Umpan

Temperatur Uap

Tekanan Kerja Max $\left(\mathrm{Kg} / \mathrm{cm}^{2}\right)$

Suhu Uap Lanjut

Temperatur Gas Buang

Luas Pemanas

Luas Panggang

Bahan Bakar
: Pepcock

: Water Tube Boiler

: 1986

: K. Uap Darat Tetap

: $18-20$ ton/jam

$: 90^{\circ} \mathrm{c}$

$: 280^{\circ} \mathrm{c}$

$: 24$

$: 260^{\circ} \mathrm{c}$

$: 370^{\circ} \mathrm{c}$

: $634 \mathrm{~m}^{2}$

$: 12 / \mathrm{m}^{2}$

: Cangkang Dan Serabut

Berdasarkan data diatas waktu rata-rata operasi boiler/hari selama 17,70 jam. Dan jika nilai tersebut dikalikan dengan kapasitas uap $15.600 \mathrm{~kg}$ uap/jam maka diperoleh nilai $284.388 \mathrm{~kg}$ uap/hari. Untuk mengetahui kapassitas uap yang dibutuhkan selama satu bulan maka nilai uap yang dibutuhkan per/hari dikalikan dengan jam kerja pabrik selama satu bulan (25 hari kerja). Dan diperoleh hasil 7.109.700 kg/bulan.

Untuk mengetahui jumlah cangkang yang dibutuhkan perbulan maka dapat dihitung dengan perhitungan jumlah TBS rata-rata yang diolah sebagai berikut.

Serabut $\quad=14 \% \times 12.580 .138 \mathrm{~kg}=1.751 .219 \mathrm{~kg}$

Cangkang $\quad=7 \% \quad$ x $12.580 .138 \mathrm{~kg}=880.609,66 \mathrm{~kg}$

\section{$\underline{\text { Nilai Kalor Serabut (N.K) }}$}

Komposisi Air $\quad=39,8 \% \times 1.751 .219 \mathrm{~kg}$

$$
=700.919,16 \mathrm{~kg}
$$


Kadar Zat Padat $\quad=55,6 \% \times 1.751 .219 \mathrm{~kg}$

$$
=976.237 \mathrm{~kg}
$$

Kadar Minyak

$$
\begin{aligned}
& =4.65 \% \times 1.751 .219 \mathrm{~kg} \\
& =81.896 \mathrm{~kg}
\end{aligned}
$$

Heating Value

$$
\begin{array}{ll}
\text { NOS } & =3.850 \mathrm{kcal} / \mathrm{kg} \\
\text { OIL } & =8.800 \mathrm{kcal} / \mathrm{kg}
\end{array}
$$

Heat Ovaporation

Water

$$
=600 \mathrm{kcal} / \mathrm{kg}
$$

N.K Serabut

$$
\begin{aligned}
& =\frac{(976.382,73 \times 3.850)+(81.896,65 \times 8.800)-(600 \times 700.919,16)}{1.761 .219} \\
& =2.304 \mathrm{kcal} / \mathrm{kg}
\end{aligned}
$$

\section{Nilai Kalor Cangkang (N.K)}

Komposisi Air $\quad=23,5 \%$ x 880.609,66 kg/bulan

$$
=206.943,27 \mathrm{~kg} / \mathrm{bulan}
$$

Kadar Zat Padat $\quad=75,9 \% \times 880.609,66 \mathrm{~kg} / \mathrm{bulan}$

$=668.382,73 \mathrm{~kg} / \mathrm{bulan}$

Kadar Minyak $\quad=0,6 \%$ x $880.609,66 \mathrm{~kg} / \mathrm{bulan}$

$$
=5.283,65 \mathrm{~kg} / \mathrm{bulan}
$$

Heating Value

$$
\begin{array}{ll}
\text { NOS } & =4.700 \mathrm{kcal} / \mathrm{kg} \\
\text { OIL } & =8.800 \mathrm{kcal} / \mathrm{kg}
\end{array}
$$

Heat Ovaporation

Water

$=600 \mathrm{kcal} / \mathrm{kg}$

N.K Cangkang

$$
=\frac{(668.382,73 \times 4.700)+(5.283,65 \times 8.800)-(600 \times 206.943,27)}{880.609,66}
$$




$$
=3.479 \mathrm{kcal} / \mathrm{kg}
$$

\section{Produksi Uap Yang Dihasilkan Boiler}

Produksi uap dari seluruh bahan bakar serabut $=1.751 .219 \mathrm{~kg}$

$\eta$

$$
\begin{aligned}
& =\frac{Q(\Delta \text { Entalphy })}{\text { Gbb } N K} \\
& =\frac{Q(710,9-90,3)}{1.751 .219 \times 2.304} \\
& =\frac{(1.751 .219 \times 2.304) \times 0,73}{620,6} \\
& =4.773 .170,25 \mathrm{~kg} \text { uap } / \mathrm{bulan}
\end{aligned}
$$$$
\text { Q }
$$

Bahan bakar cangkang yang diperlukan untuk mencukupi 7.109.700 kg uap/bulan

$$
\begin{aligned}
& \eta \quad=\frac{Q(\Delta E n t a l p h y)}{G b b \times N K} \\
& 0,73=\frac{\mathrm{Q}(710,9-90,3)}{\mathrm{Gbb} \times 3.479} \\
& \text { Gbb } \quad=\frac{(7.109 .700-4.733,25) \times 620,6}{0,73 \times 3.479} \\
& =\frac{1.450 .050 .362,85}{2.540} \\
& =570.885,96 \mathrm{~kg} / \mathrm{bulan}
\end{aligned}
$$

Sisa Cangkang $\quad=880.609,66-570.885,96=303.723 \mathrm{~kg}$

Kalori Yang Terkandung dari 570.885,66 x $3.479 \mathrm{kcal}=1.986 .112 \mathrm{kcal} / \mathrm{bulan}$

Dari data rata-rata TBS yang diolah perbulan pada tahun 2019 di dapatkan hasil penggunaan cangkang perbulan mencapai 570.885,96 kg/bulan. Kebutuhan cangkang tersebut masih dapat dipenuhi dengan persediaan yang ada pada TBS yang diolah oleh PKS Kebun Adolina. Sisa bahan bakar cangkang sebanyak $303.723 \mathrm{~kg}$.

Untuk mengetahui penggunaan bahan bakar cangkang dan serabut yang terpakai pada PKS Kebun Adolina dengan kapasitas 30 ton perjam. Maka dilakukan pengolahan data yang diambil dari data yang terkecil dari jumlah TBS olah pada tahun maret 2018 - februari 2019, adapun data terpilih terdapat pada bulan februari dengan TBS diolah sebanyak $5.679 .890 \mathrm{~kg}$.

$$
\begin{array}{lll}
\text { Serabut } & =14 \% \times 5.679 .890 \mathrm{~kg} & =795.184 \mathrm{~kg} / \mathrm{bulan} \\
\text { Cangkang } & =7 \% \times 5.679 .890 \mathrm{~kg} &
\end{array}
$$


Nilai Kalor Serabut (N.K)

Komposisi Air

Kadar Zat Padat (N.O.S)

Kadar Minyak

Heating Value NOS

OIL

Heat Evaporation Water

N.K Serabut

Komposisi Air

Kadar Zat Padat

Kadar Minyak

$=0,6 \% \times 397.592 \mathrm{~kg}$

$=2.385 \mathrm{~kg} / \mathrm{bulan}$

Heating Value

$\begin{array}{ll}\mathrm{NOS} & =4.700 \mathrm{kcal} / \mathrm{kg} \\ \mathrm{OIL} & =8.800 \mathrm{kcal} / \mathrm{kg}\end{array}$

$=39,8 \% \times 795.184 \mathrm{~kg}$

$=316.483 \mathrm{~kg}$

$=55,6 \% \times 795.184 \mathrm{~kg}$

$=444.122 \mathrm{~kg}$

$=4.65 \% \times 795.184 \mathrm{~kg}$

$=36.976 \mathrm{~kg}$

$=3.850 \mathrm{kcal} / \mathrm{kg}$

$=8.800 \mathrm{kcal} / \mathrm{kg}$

$=600 \mathrm{kcal} / \mathrm{kg}$

$=2.310 \mathrm{kcal} / \mathrm{kg}$

$=23,5 \%$ x $397.592 \mathrm{~kg}$

$=93.434 \mathrm{~kg} / \mathrm{bulan}$

$=75,9 \%$ x $397.592 \mathrm{~kg}$

$=301.772 \mathrm{~kg} / \mathrm{bulan}$

$$
=2.385 \mathrm{~kg} / \mathrm{bulan}
$$

Heat Evaporation Water

$=\frac{(442.122 \times 3.850)+(36.976 \times 8.800)-(600 \times 316.483)}{795.184}$

$$
=600 \mathrm{kcal} / \mathrm{kg}
$$


N.K Serabut

$$
\begin{aligned}
& =\frac{(301.772 \times 4.700)+(2.385 \times 8.800)-(600 \times 93.434)}{397.592} \\
& =3.479 \mathrm{kcal} / \mathrm{kg}
\end{aligned}
$$

Produksi uap dari seluruh bahan bakar serabut $=795.184 \mathrm{~kg}$

$\eta$

$$
=\frac{Q(\Delta \text { Entalphy })}{G b b \times N O}
$$

$$
=\frac{Q(\Delta E n t a l p h y)}{G b b \times N O} Q(710,9-90,3)
$$

$795.184 \times 2.310$

Q

$$
=\underline{(795.184 \times 2.130) \times 0,73}
$$

620,6

Q

$$
=2.160 .681,24 \mathrm{~kg} \text { uap } / \mathrm{bulan}
$$

Bahan bakar cangkang yang diperlukan untuk mencukupi 7.109.700 kg uap perbulan

$\eta$

$$
=\frac{Q(\Delta \text { Entalphy })}{G b b \times N K}
$$

$$
=\frac{Q(710,9-90,03)}{G b b \times 3.479}
$$

$\mathrm{Gbb}$

$$
=\frac{Q(7.109 .700-2.160 .681) \times 620,6}{0,73 \times 3.479}
$$

$\mathrm{Gbb}$

$$
=\frac{3.071 .361}{2.540}
$$

$\mathrm{Gbb}$

$$
=1.209,19 \mathrm{~kg} / \mathrm{bulan}
$$

Sisa Cangkang

$$
\begin{aligned}
& =397.592-1.209,19 \\
& =396.382,81 \mathrm{~kg}
\end{aligned}
$$

Dari pengolahan data diatas untuk pengolahan 5.679.890 kg TBS dibulan januari. Dengan memakai uap 7.109.700 kg/bulan. Kebutuhan cangkang tersebut masih dapat terpenuhi dengan persediaan yang ada pada TBS yang diolah oleh PKS Kebun Adolina. Sisa bahan bakar cangkang sebanyak $396.382,81 \mathrm{~kg}$. Hal ini terjadi karena perhitungan menggunakan bilangan uap rata - rata 
perbulan. Namun jika bilangan TBS diolah dibagikan dengan kapasitas pabrik (30 ton/jam) maka diperoleh jam operasi boiler selama 7 jam 57 menit. Perhitunganya sebagai berikut :

TBS olah bulan februari $2019: 5.679 .890 \mathrm{~kg}$

Kapasitas Pabrik Perjam $\quad$ : $30.000 \mathrm{~kg} / \mathrm{jam}$

Hari Kerja Perbulan $\quad: 25$ Hari

Jam Operasi Perbulan $\quad: \frac{\text { TBS Olah }}{\text { Kapasitas Pabrik }}$

$: \frac{5.679 .890}{30.000}$

$: 189.32$

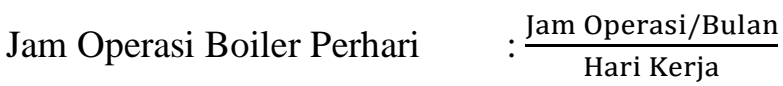

$: \frac{189,32}{25}$

: 7,57 Jam

Maka kebutuhan uap keseluruhan pada bulan januari 2019 ialah :

$15.600 \mathrm{~kg} \mathrm{uap} / \mathrm{jam} \times 189 \mathrm{jam}=2.948 .400 \mathrm{~kg}$ uap $/$ bulan

Analisa Persediaan Cangkang dan Serabut

Cangkang dan serabut digunakan sebagai bahan bakar boiler dimana boiler merupakan sebuah alat yang dapat menghasilkan uap untuk dapat memutar elektro motor yang ada pada turbin. Pentingya persediaan bahan bakar cangkang dan serabut harus selalu di usahakan tetap tersedia agar pabrik tetap beroperasi.

Dari pengolahan data yang telah dilakukan persediaaan cangkang dan serabut tiap tahun ialah sebagai berikut :

Maret 2016 - Februari 2017 persediaan cangkang sebanyak $11.540 .735 \mathrm{~kg}$ dan serabut sebanyak $19.390 .306 \mathrm{~kg}$.

Maret 2016 - Februari 2017 persediaan cangkang sebanyak $10.558 .125 \mathrm{~kg}$ dan serabut sebanyak $18.346 .265 \mathrm{~kg}$.

Maret 2016 - Februari 2017 persediaan cangkkang sebanyak $9.773 .950 \mathrm{~kg}$ dan serabut sebanyak $17.548 .036 \mathrm{~kg}$. 
Analisa Kebutuhan Cangkang dan serabut

Dari pengolahan data yang telah dilakukan kebutuhan cangkang dan serabut tiap tahun ialah sebagai berikut :

Maret 2016 - Februari 2017 kebutuhan cagkang sebanyak $10.459 .574 \mathrm{~kg}$ dan serabut sebanyak $19.390 .306 \mathrm{~kg}$.

Maret 2016 - Februari 2017 kebutuhan cangkang sebanyak $9.303 .613 \mathrm{~kg}$ dan serabut sebanyak $18.346 .265 \mathrm{~kg}$.

Maret 2016 - Februari 2017 kebutuhan cangkang sebanyak $8.764 .511 \mathrm{~kg}$ dan serabut sebanyak $17.548 .026 \mathrm{~kg}$.

Dari kedua analisa dapat dikatakan bahwa kebutuhan bahan bakar cangkang dan serabut selalu terpenuhi. Dimana ketersediaan cangkang yang selalu menunjukkan nilai lebih tinggi dibandingkan dengan kebutuhan seementara ketersediaan serabut dipakai secara maksimal dan tidak memiliki sisa. Hal ini dikarenakan perusahaan selalu menggunakan serabut lebih utama dikhawatirkan jika serabut yang siap pakai tidak langsung diolah (dibakar) dapat mengganggu kinerja mesin yang ada di dalam pabrik. Ketersediaan bahan bakar cangkang dan kebutuhan cangkang dapat dilihat pada gambar 4.1 sedangkan ketersediaan serabut dan kebutuhan serabut dapat dilihat pada figure 2 .

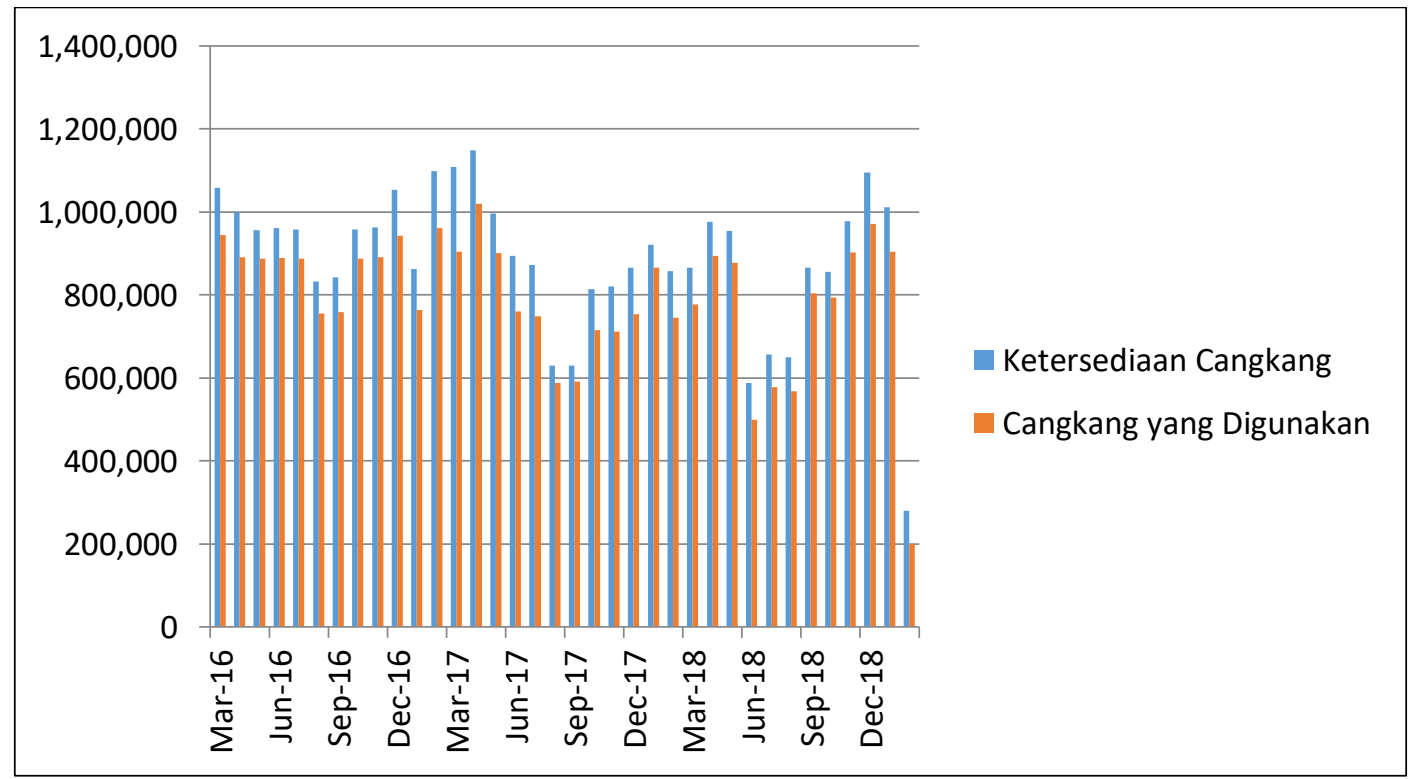

Figure 2 Grafik Ketersediaan Bahan Bakar Cangkang Dan Kebutuhan Cangkang 


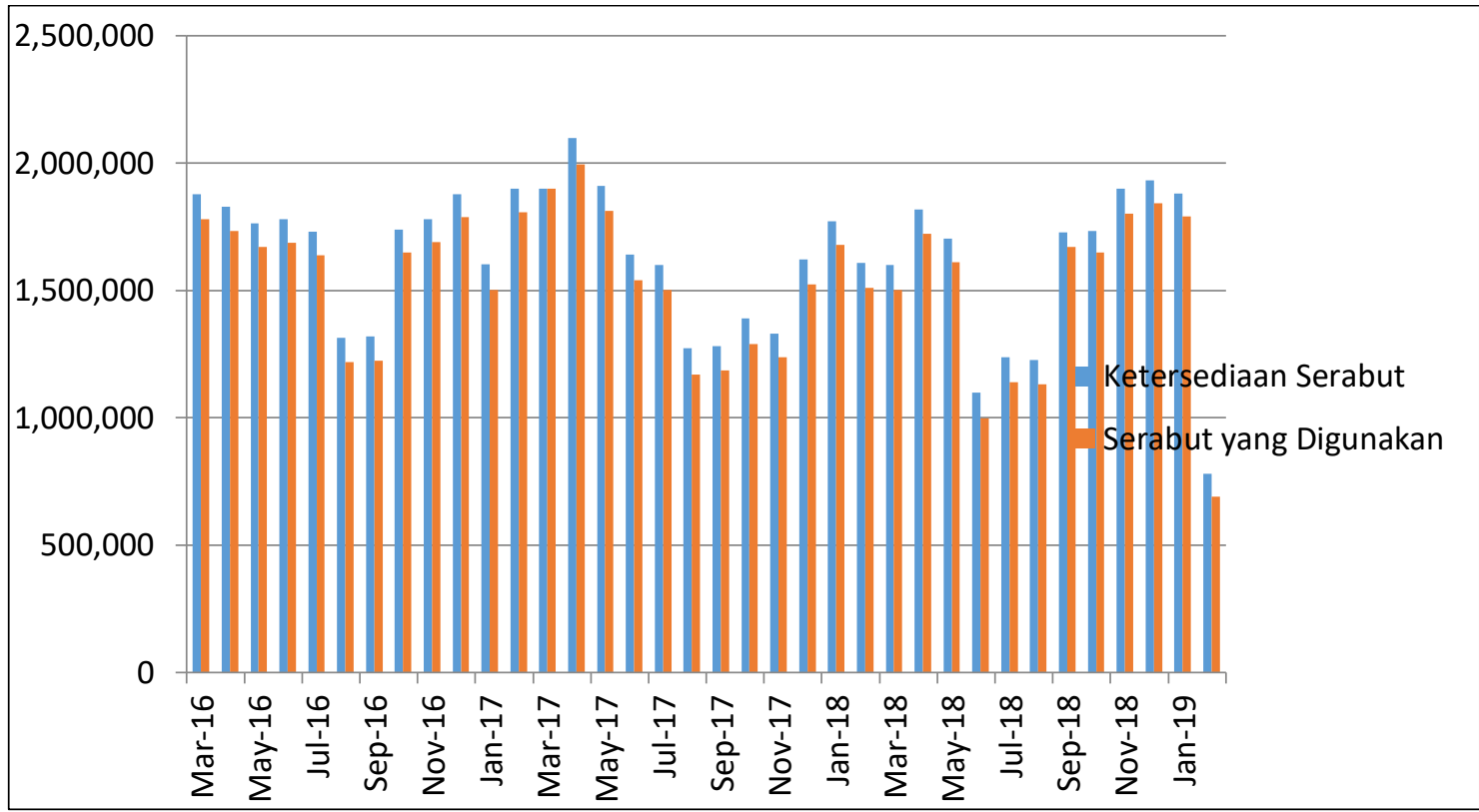

Figure 3 Grafik Ketersediaan Dan Kebutuhan Serabut

Dari grafik ketersediaan cangkang dan kebutuhan cangkang dapat dilihat bahwa perusahaan tidak pernah mengalami kekurangan dalam masalah penyediaan cangkang. Ini berarti perusahaan tidak perlu membeli cangkang dari pihak luar.

Jadi dari keterangan diatas dapat diketahui bahwa dengan kapasitas $30.000 \mathrm{~kg}$ uap/jam ketersedian bahan bakar berupa cangkangdan serabut untuk menghasilkan kebutuhan uap sebanyak $15.600 \mathrm{~kg}$ uap/jam tidak dikhawarikan adanya kekurangan baik dari kedua bahan bakar tersebut. Dengan kata lain dapat dikatakan bahwa PKS PTPN IV Kebun Adolina dapat memenuhi kebutuhan bahan bakar cangkang dan serabut yang diproduksi sendiri tanpa mengadakan (membeli) dari pihak luar.

\section{Kesimpulan}

Kesimpulan yang dapat diambil sebagai berikut :

a. Kebutuhan rata-rata pada tahun 2018 maret - 2019 februari cangkang sebanyak $730.375 \mathrm{~kg}$ dan serabut sebanyak $1.462 .336 \mathrm{~kg}$.

b. Ketersediaan rata-rata pada tahun 2018 maret - 2019 februari cangkang sebanyak 814.495 $\mathrm{kg}$ dan serabut sebanyak $1.553 .473 \mathrm{~kg}$.

c. Dari kedua poin diatas kebutuhan bahan bakar boiler telah tercukupi baik cangkang maupun serabut. Bahkan pada bahan bakar cangkang masi memiliki sisa sebanyak $84.119 \mathrm{Kg}$ dan serabut $91.136 \mathrm{Kg}$.

d. PTPN IV Kebun Adolina tidak perlu melakukan stok guna untuk memenuhi bahan bakar boiler. Dikarenakan ketersediaan cagkang dan serabut selalu mencukupi untuk operasi pabrik. 
e. Total persediaan cangkang dan serabut yang harus dikeluarkan pada tahun 2018 maret 2019 februari ialah cangkan sebanyak $9.773 .950 \mathrm{~kg}$ dan serabut sebanyak $18.641 .681 \mathrm{~kg}$.

f. Bahan bakar solar yang dibutuhkan boiler rata - rata dari bulan maret 2016 - februari 2019 berjumlah 557 liter/bulan, jika dikalikan dengan harga solar yang mencapai Rp. 9.800/liter maka PKS Kebun Adolina akan mengeluarkan biaya sebesar Rp. 5.458.600 Penggunaan bahan bakar solar masih dianggap wajar oleh PKS Kebun Adolina.

\section{REFERENSI}

[1] Barus Takal, 2017. Energi Terbarukan PKS 30 TON. Harian Waspada 27 Agustus 2017. Medan.

[2] Dokumen Intern PTPN IV Kebun Adolina(2018) "Pengantar Proses Quality Control, Quality Control Tools For Procesing improvement In Palm Oil” PKS Kebun Adolina.

[3] Djokoseyarjo, M. J. (2006) "Ketel Uap" Pradya Pramita, Jakarta.

[4] Parinduri, Luthfi (2016) "Analisa Pemanfaatan Biomassa Pabrik Kelapa Sawit Untuk Sumber Pembangkit Tenaga Listrik" Journal Of Electrical Tecnology, Fakultas Teknik Universitas Islam Sumatera Utara, Medan.

[5] Syafrudin, Hanesya Rio (2012) "Prosiding Seminar Nasional Aplikasi Sains Dan Teknologi (SNAST) Prriode 3, Perbandingan Pengggunaan Alternatif Bahan Bakar Serabut (Fiber) Dan Cangkang Kelapa Sawit Terhadap Bahan Bakar Batu Bara Dan Solar Pada Pembangkit Listrik" Fakultas Industri, Institut Sains Dan Teknologi AKPRIND, Yogyakarta.

[6] Affan, Chairil (2016) "Analisa Kebutuhan Bahan Bakar Boiler Pabrik Kelapa Sawit PTPN IV (PERSERO) Kebun Dolok Sinumbah” Skripsi Fakultas Teknik, Universitas Islam Sumatera Utara, Medan. 